\title{
ANALSISI PERILAKU MASYARAKAT TERHADAP KEPUTUSAN MENGUNJUNGI DESTINASI WISATA SYARIAH DI SUMATERA BARAT
}

\author{
Ainun Mardiah \\ Fakultas Ekonomi dan Ilmu Sosial UIN Suska Riau \\ ainun_pbr@yahoo.com \\ Herlinda \\ Fakultas Ekonomi dan Ilmu Sosial UIN Suska Riau \\ herlinda@uin-suska.ac.id
}

\begin{abstract}
This study aims to determine the influence of consumer behavior consisting of cultural, social, individual, and psychological factors which have simultaneous and partial influence on the decision to visit the Shariah tourism destination in West Sumatra. The number of sample is 100 respondents. The research variables consist of independent variables are culture (X1), social (X2), individual (X3), psychological (X4) as well as the dependent variable $(Y)$ is the decision to visit the destination of sharia tourism. Data analysis used multiple linear regression analysis. The result of research indicate that culture has significant influence to the decision to visit shariah tourism destination, social has significant effect to the decision to visit the shariah tourism destination, the individual has a significant effect on the decision to visit the sharia tourism destination, the psychology has significant effect to the decision to visit the sharia tourist destination. Based on $F$ test, it is found that cultural, social, individual and psychological variables influence together to the decision to visit the Shariah tourism destination in West Sumatera.
\end{abstract}

Keywords: shariah tourism, culture, social, individual, psychological.

\section{PENDAHULUAN}

Indonesia mempunyai populasi muslim terbesar di dunia sehingga sangat berpeluang sekali dalam menyambut wisatawan muslim. Kemudian didukung pula oleh fakta bahwa industri dan perdagangan syariah di Indonesia yang meningkat sehingga jaminan halal dan sharia compliance pun makin meningkat. Selain itu telah hadir pelaku-pelaku industri pariwisata syariah yang cukup mapan dan profesional.

Salah satu bentuk pariwisata syariah yang dipersepsikan sangat melekat adalah wisata religi, wisata spiritual dan wisata pengenalan Islam untuk umum serta peninggalan sejarah dan bangunan masjid yang tersebar hampir di seluruh pelosok nusantara.

Kemenparekraf RI telah mengembangkan dan mempromosikan usaha jasa di bidang perhotelan, restoran, biro perjalanan wisata dan spa di 12 destinasi wisata syariah. Pengembangan tersebut dilakukan di sejumlah kota yaitu Aceh, Sumatera Barat, Riau, Lampung, Banten,
Jakarta, Jawa Barat, Jawa Tengah, Yogyakarta, Jawa Timur, NTB serta Sulawesi Selatan.

Sumatera Barat merupakan salah satu destinasi wisata syariah yang mempunyai banyak objek-objek wisata menarik untuk dikunjungi. Didukung dengan transportasi yang memadai, objek-objek wisata tersebut sangat mudah dijangkau. Selain itu, derdapat juga beberapa penghargaan yang dapat menjadi indikator keberhasilan Sumatera Barat dalam mempersiapkan destinasi wisata syaraiah.

Pada tahun 2016 dalam World Halal Tourism Award (WHTA) yang diadakan di Abu Dhabi Uni Emirat Arab, Sumatera Barat mendapatkan tiga gelar yaitu World's Best Halal Tour Operator melalui Ero Tour, World's Best Halal Destination, dan World's Best Halal Culinary Destination. Keberhasilan Sumatera Barat dalam World Halal Tourism Award WHTA 2016 ini merupakan langkah yang baik dalam pengembangan wisata halal di Sumatera Barat. 
Oleh karena itu untuk dapat mewujudkan Sumatera Barat sebagai salah satu destinasi wisata syariah adalah perlunya dukungan dari masyarakat terhadap pengembangan kepariwisataan di Sumatera Barat. Perilaku masyarakat terhadap keputusan untuk mengunjungi destinasi wisata halal di Sumatera Barat haruslah diketahui dan dipahami oleh para pelaku usaha jasa pariwisata sehingga usaha untuk memenuhi kebutuhan wisatawan dapat tercapai.

Permasalahan yang dikemukakan dalam penelitian ini adalah apakah faktor budaya, sosial, individu dan psikoligis berpengaruh secara simultan maupun parsial terhadap keputusan masyarakat dalam mengunjungi destinasi wisata syaraiah di Sumatera Barat.

Sangatlah penting bagi pemerintah daerah dan pelaku usaha pariwisata Sumatera Barat untuk mengidentifikasi dan menganalisa perilaku masyarakat dalam memutuskan untuk mengunjungi wisata syariah di Sumatera Barat. Semua pihak di Sumatera Barat harus berusaha menarik perhatian masyarakat muslim maupun yang non muslim dengan cara memenuhi kebutuhan dan keinginan para wisatawan.

Beberapa faktor yang mempengaruhi perilaku seorang konsumen diantaranya adalah lingkungan keluarga, kelompok sosial, tempat kerja, agama, situasi yang terjadi, norma-norma yang berlaku dan lain-lain. Menurut Kotler (2001), faktor-faktor yang mempengaruhi perilaku konsumen adalah. Budaya, sosial, individu dan psikologis.

Penelitian ini bertujuan untuk menganalisis dan mengetahui pengaruh perilaku konsumen yang terdiri dari fakor budaya, sosial, individu, dan psikologis mempunyai pengaruh simultan maupun parsial terhadap keputusan mengunjungi destinasi wisata syariah di Sumatera Barat.

Pariwisata syariah merupakan pariwisata yang mengedepankan nilai-nilai Islami dalam setiap aktivitasnya. Namun, istilah pariwisata yang mengedepankan nilai-nilai Islami dalam setiap aktivitasnya. Namun istilah pariwisata syariah secara definisi di kalangan pelaku wisata masih cenderung asing. Pariwisata syariah lebih dimaknai sebagai wisata religius, yaitu kunjungan-kungjungan ke tempat ibadah untuk berziarah atau tempat-tempat ibadah lainnya. Padahal, wisata syariah tidak terfokus pada objek saja, tetapi adab perjalanan dan fasilitas lainnya (Chookaew, 2015).

Kepariwisataan berbasis syariah dipahami sebagai produk-produk kepariwisataan yang menyediakan layanan keramahtamahan yang memenuhi persyaratan syar'i (Romli, 2011). Hal ini berarti orang yang sedang berwisata, harus mematuhi laranganlarangan agama seperti berasik-asik di pantai dan kolam renang, makan dan minum di hotel atau restoran dengan menu hidangan yang mengandung alkohol atau babi dan makanan lain nya yang haram.

Menurut Salama (2013), pada tahun 2011 belanja para wisatawan muslim di berbagai tujuan wisata di seluruh negara diperkirakan mencapai USD 126 miliar dan jumlah ini diharapkan naik hingga USD 192 miliar pada tahun 2020. Oleh karena itu sejumlah negara berinisiatif untuk menarik para wisatawan muslim agar berkunjung ke negaranya dengan mempersiapkan hotel yang berbasis syariah.

Segmen pasar produk dan jasa berbasis syariah bukan hanya untuk kaum muslimin, namun juga non muslim. Hal ini karena konsumsi produk dan jasa berbasis syariah berefek baik, sehat dan mengangkat gaya hidup (Ramli, 2011).

Produk-produk wisata berbasis syariah dapat mencakup kunjungan aktivitas seperti shopping, traveling, taman hiburan, kota-kota yang sangat padat, warisan budaya islami, hotel dan resort berbasis syariah yang tidak menawarkan minuman beralkohol, makanan yang mengandung babi dan semua produk turunannya, tempat dan jadwal sholat, tanda arah kiblat di kamar, kolam renang dan spa serta fasilitas lainnya yang memisahkan konsumen perempuan dan laki-laki, dan lainlain.

Jadi objek pariwisata syariah tidak mesti harus objek yang bernuansa Islam, seperti masjid dan peninggalan sejarah Islam. Objek pariwisata syariah berlaku untuk semua 
tempat, kecuali tempat ibadah agama lain. Pariwisata syariah memberikan makna bahwa masyarakat muslim harus berIslam dimanapun dan kapanpun.

Pemaknaan yang kurang tepat terkait pariwisata syariah disebabkan karena edukasi yang kurang. Dari sudut pandang wisatawan, ketersediaan informasi yang kurang adalah penyebab utama ketidakpahaman tentang pariwisata syariah. Dari sudut pandang pelaku bisnis, pariwisata syariah belum dikenal karena belum adanya panduan-panduan jelas terkait pariwisata syariah.

Beberapa prinsip pengembangan wisata berbasis syariah mencakup (1) pengembangan fasilitas wisata berbasis syariah dalam skala besar atau kecil beserta pelayanan di luar dan di dalam atau dekat lokasi wisata, (2) fasilitas dan pelayanan berbasis syariah tersebut dimiliki dan dikerjakan oleh masyarakat setempat, yang dilakukan dengan bekerja sama atau dilakukan secara individual oleh yang memiliki, (3) pengembangan wisata berbasis syariah didasarkan pada salah satu "sifat" budaya tradisional yang lekat pada suatu lingkungan religius atau "sifat" atraksi berbasis syariah yang dekat dengan alam dimana pengembangan lingkungan sebagai pusat pelayanan berbasis syariah bagi wisatawan yang mengunjungi kedua atraksi tersebut.

\section{METODE}

Pendekatan dalam penelitian ini menggunakan penndekatan kuantitatif. Dalam hal ini peneliti menggunakan variabel-variabel penelitian berdasarkan teori perilaku konsumen oleh Kotler (2009) yang terdiri dari variabel bebasnya adalah budaya $\left(\mathrm{X}_{1}\right)$, sosial $\left(\mathrm{X}_{2}\right)$, individu $\left(\mathrm{X}_{3}\right)$, psikologis $\left(\mathrm{X}_{4}\right)$ serta variabel terikat $(\mathrm{Y})$ nya adalah keputusan mengunjungi destinasi wisata syariah.

Populasi dalam penelitian ini adalah seluruh masyarakat Sumatera Barat yang berjumlah 914.968 jiwa (BPS Padang, 2017). Jumlah sampel adalah sebanyak 100 orang responden. Metode pengambilan sampel yang digunakan untuk menentukan sampel adalah metode accidental sampling.

Kemudian pengumpulan data dilakukan dengan memberikan kuesioner atau daftar pertanyaan kepada responden. Kuesioner berisi variabel-variabel perilaku dan keputusan masyarakat dalam mengunjungi destinasi wisata syariah di Sumatera Barat. Setiap pertanyaan dalam kuesioner terdiri dari lima alternatif jawaban dan masing-masing diberi skor yaitu Sangat Setuju (skor 5), Setuju (skor 4), Netral (3), Tidak Setuju (skor 2) dan Sangat Tidak Setuju (skor 1).

Teknik analisa data menggunakan analisis regresi berganda dengan menggunakan persamaan $\mathrm{Y}=\mathrm{a}+\mathrm{b} 1 \mathrm{X} 1+$ $\mathrm{b} 2 \mathrm{X} 2+\mathrm{b} 3 \mathrm{X} 3+\mathrm{b}_{4} \mathrm{X}_{4}+$ e. Dimana $\mathrm{Y}$ adalah keputusan mengunjungi destinasi wisata syariah, $\mathrm{X}_{1}$ adalah budaya, $\mathrm{X}_{2}$ adalah sosial, $\mathrm{X}_{3}$ adalah individu, $\mathrm{X}_{4}$ adalah psikologis, e adalah error, a adalah konstanta, $b_{1} b_{2} b_{3} b_{4}$ adalah koefisien regresi.

\section{HASIL DAN PEMBAHASAN}

Tabel descriptive statistics menunjukkan angka minimum, maksimum, mean dan standar deviasi dari penyebaran data hasil rekap kuesioner mengenai variabel budaya, sosial, individu psikologis dan keputusan mengunjungi destinasi wisata syariah, yaitu :

Tabel 1. Statistik Deskriptif

Descriptive Statistics

\begin{tabular}{|l|r|r|r|r|r|}
\hline & $\mathrm{N}$ & Min & Max & Mean & $\begin{array}{c}\text { Std. } \\
\text { Deviation }\end{array}$ \\
\hline Y_Keputusan & 100 & 2.00 & 5.00 & 3.5400 & .70238 \\
X1_Budaya & 100 & 1.00 & 5.00 & 3.2100 & .96708 \\
X2_Sosial & 100 & 1.00 & 5.00 & 3.2600 & 1.03103 \\
X3_Individu & 100 & 1.00 & 5.00 & 3.5500 & 1.02863 \\
X4_Psikologis & 100 & 1.00 & 5.00 & 3.6900 & .81271
\end{tabular}

Sumber: Output SPSS (data diolah)

Berdasarkan pengujian statistik diketahui bahwa nilai minimum variabel budaya sebesar 1 nilai maksimum 5 dan nilai rata-rata (mean) sebesar 3,2100 dengan standar deviasi sebesar 0,96708. Nilai ratarata dan nilai standar deviasi budaya ini menunjukkan bahwa terdapat penyebaran data yang baik karena nilai rata-ratanya lebih besar dari pada nilai standar deviasinya. 
Kemudian variabel sosial memperoleh nilai minimum sebesar 1 , nilai maksimum 5 dan nilai rata-rata (mean) sebesar 3,2600 dengan standar deviasi sebesar 1,03103. Nilai rata-rata dan nilai standar deviasi sosial ini menunjukkan bahwa terdapat penyebaran data yang baik karena nilai rata-ratanya lebih besar dari pada nilai standar deviasinya.

Variabel individu memperoleh nilai minimum sebesar 1 nilai maksimum 5 dan nilai rata-rata (mean) sebesar 3,5500 dengan standar deviasi sebesar 1,02863. Nilai ratarata dan nilai standar deviasi individu ini menunjukkan bahwa terdapat penyebaran data yang baik karena nilai rata-ratanya lebih besar dari pada nilai standar deviasinya.

Variabel psikologis memperoleh nilai minimum sebesar 1 nilai maksimum 5 dan nilai rata-rata (mean) sebesar 3,6900 dengan standar deviasi sebesar 0,81271. Nilai ratarata dan nilai standar deviasi psikologis ini menunjukkan bahwa terdapat penyebaran data yang baik karena nilai rata-ratanya lebih besar dari pada nilai standar deviasinya.

Variabel keputusan mengunjungi destinasi wisata syariah memperoleh nilai minimum sebesar 2 , nilai maksimum 5 dan nilai rata-rata (mean) sebesar 3,5400 dengan standar deviasi sebesar 0,7023 . Nilai rata-rata dan nilai standar deviasi keputusan mengunjungi destinasi wisata syariah ini menunjukkan bahwa terdapat penyebaran data yang baik karena nilai rata-ratanya lebih besar dari pada nilai standar deviasinya.

Dari statistik deskrptif tersebut, dapat disimpulkan bahwa secara keseluruhan nilai rata-rata variabel budaya, sosial, individu, psikologis dan keputusan mengunjungi destinasi wisata syariah lebih besar dari besar dari pada standar deviasinya.

Kemudian untuk uji normalitas yang bertujuan untuk mengetahui apakah distribusi sebuah data mengikuti atau mendekati distribusi normal, data yang baik adalah yang mempunyai pola seperti distribusi normal (tidak melenceng ke kiri dan ke kanan). Dari hasil pengolahan data dengan metode SPSS dapat dikemukakan bahwa nilai-nilai sebaran data terletak di sekitar garis lurus, sehingga persyaratan normalitas dapat dipenuhi seperti terlihat pada lampiran.
Pada uji validitas penelitian ini, daftar pertanyaan dilakukan dengan tujuan untuk mengetahui kehandalan angket. Kehandalan angket mempunyai arti bahwa angket mampu mengukur apa yang seharusnya diukur. Dari hasil pengolahan data mengenai indikatorindikator yang diteliti, diperoleh hasil bahwa semua butir pertanyaan adalah valid karena lebih besar dari $r$ tabel.

Setelah dilakukan uji validitasnya kemudian perlu diketahui uji reliabilitas. Uji reliabilitas ini ditunjukkan dari hasil koefisien Alpha Cronmbach dengan hasil. Nilai Alpha ini $>0,6$ yang dapat dikatakan bahwa dari seluruh indikator memiliki reliabilitas yang tinggi.

Uji multikolinearitas bertujuan untuk menguji apakah dalam suatu model regresi ditemukan adanya korelasi antar variabel bebas penelitian. Model regresi yang baik seharusnya tidak terjadi korelasi diantara variabel bebas. Ada tidaknya korelasi antar variabel tersebut dapat dideteksi dengan melihat nilai variance Inflation Factor (VIF).

VIF merupakan kebalikan dari tolerance jika nilai tolerance yang rendah sama dengan nilai VIF tinggi (karena VIF = tolerance). Cara umum yang dipakai untuk menunjukkan multikolinearitas adalah jika nilai tolerance < 0,10 atau sama dengan VIF $>10,00$ maka terjadi multikolinearitas dalam penelitian ini. Hasil uji multikolinearitas dapat dilihat tabel berikut :

Tabel 2. Hasil Uji Multikolinearitas

\begin{tabular}{|c|c|c|c|}
\hline \multirow{2}{*}{ Model } & \multicolumn{2}{|c|}{ Colinearity Statistics } & \multirow{2}{*}{ Keterangan } \\
\hline & Tolerance & VIF & \\
\hline Budaya & 0,631 & 1,586 & $\begin{array}{c}\text { Bebas } \\
\text { multikolinearitas }\end{array}$ \\
\hline Sosial & 0,591 & 1,693 & $\begin{array}{c}\text { Bebas } \\
\text { multikolinearitas }\end{array}$ \\
\hline Individu & 0,860 & 1,163 & $\begin{array}{c}\text { Bebas } \\
\text { multikolinearitas }\end{array}$ \\
\hline psikologis & 0,819 & 1,220 & $\begin{array}{c}\text { Bebas } \\
\text { multikolinearitas }\end{array}$ \\
\hline
\end{tabular}

Sumber: Output SPSS (data diolah)

Berdasarkan hasil pada tabel di atas dapat diketahui bahwa hasil uji multikolinearitas seluruh variabel memiliki nilai tolerance berada di atas atau $>0,10$ dan nilai VIF di bawah atau $<10,00$. Jadi disimpulkan bahwa model regresi bebas dari pengaruh multikolinearitas. 
Uji autokorelasi adalah hubungan atau korelasi antara data yang satu dengan data yang lainnya dalam satu variabel. Autokorelasi ini dapat terjadi pada variabel dependen atau variabel independen (karena terdapat dalam satu lajur). Teknik pengujian autokorelasi adalah Durbin-Watson Test.

Uji autokorelasi bertujuan menguji apakah model regresi linier ada korelasi antara kesalahan pengganggu pada periode $t$ dengan kesalahan pengganggu pada periode sebelumnya $(\mathrm{t}-1)$. Jika terjadi korelasi, maka dalam hal ini terdapat problem autokorelasi.

Hasil pengujian autokorelasi dari penelitian ini dapat dilihat dari tabel berikut :

Tabel 3. Hasil Uji Autokorelasi

\begin{tabular}{ccc}
\hline Durbin-Watson & $\mathbf{n}$ & Keterangan \\
\hline 1,888 & 100 & $\begin{array}{c}\text { Tidak terdapat } \\
\text { autokorelasi }\end{array}$ \\
\hline Sumber : Output SPSS (data diolah) \\
Dari hasil perhitungan dengan SPSS,
\end{tabular}
diperoleh nilai $\mathrm{d}$ hitung sebesar 1,888. Dengan menggunakan persamaan $\mathrm{du}<\mathrm{d}<4$ $\mathrm{dl}$, dumana jika angka d-hitung berada di atas batas (du) dengan kurang dari 4-dl, maka tidak terdapat autokorelasi positif atau negatif.

Untuk melihat tabel, maka digunakan $\mathrm{k}$ $=4, \alpha=5 \%$ dan $\mathrm{n}=100$, maka du $=1$, 7582, dl (batas bawah) $=1,5922$, nilai DW sebesar 1,888 lebih besar dari batas atas (du) 1,7582 dan kurang dari 4-1,5922 (4-dl), maka dapat disimpulkan tidak terdapat autokorelasi.

Pengujian adanya heterokedastisitas dilakukan dengan menggunakan scatterplot yang diperoleh dengan bantuan software SPSS. Heterokedastisitas adalah ketidaksamaan varian residual dari suatu model regresi. Uji heterokedastisitas menguji apakah dalam model regresi terjadi ketidaksamaan varian residual dari satu observasi dengan yang lain.

Model regresi berganda bertujuan untuk memprediksi besar variabel dependen dengan menggunakan data variabel independen yang sudah diketahui besarnya. Adapun hasil analisis regresi berganda sebagai berikut :
Tabel 4. Analisis Regresi Berganda Coefficients $^{a}$

\begin{tabular}{|c|c|c|c|c|c|}
\hline \multirow[b]{2}{*}{ Model } & \multicolumn{2}{|c|}{$\begin{array}{c}\text { Unstandardiz } \\
\text { ed } \\
\text { Coefficients }\end{array}$} & \multirow{2}{*}{\begin{tabular}{|c}
$\begin{array}{c}\text { Standar } \\
\text { dized } \\
\text { Coeffici } \\
\text { ents }\end{array}$ \\
Beta
\end{tabular}} & \multirow[b]{2}{*}{$\mathrm{t}$} & \multirow[b]{2}{*}{ Sig. } \\
\hline & B & $\begin{array}{l}\text { Std. } \\
\text { Error }\end{array}$ & & & \\
\hline 1 (Constant) & .286 & .131 & & 2.175 & .032 \\
\hline X1_Budaya & .399 & .032 & .549 & 12.631 & .000 \\
\hline X2_Sosial & .109 & .031 & .161 & 3.576 & .001 \\
\hline X3_Individu & .060 & .025 & .088 & 2.375 & .020 \\
\hline X4_Psikologis & .380 & .033 & .440 & 11.540 & .000 \\
\hline
\end{tabular}

a. Dependent Variable:

Y_Keputusan

Sumber : Data Primer

Berdasarkan kepada tabel diatas maka diperoleh model persamaan regresi linier berganda sebagai berikut : $\mathrm{Y}=0,286+$ $0,399 \mathrm{X}_{1}+0,109 \mathrm{X}_{2}+0,060 \mathrm{X}_{3}+0,380 \mathrm{X}_{4}$.

Persamaan di atas menunjukkan bahwa koefisien regresi variabel budaya $\left(\mathrm{X}_{1}\right)=0,399$ ini menunjukkan besarnya pengaruh variabel tersebut terhadap keputusan mengunjungi destinasi wisata syariah. Tanda positif menunjukkan koefisien arah hubungan yang positif. Dengan arti setiap ada kenaikan satu satuan variabel budaya maka keputusan mengunjungi destinasi wisata syariah akan naik sebesar 0,399 kali dengan anggapan faktor yang lain konstan (ceteris paribus).

Koefisen regresi variabel sosial $\left(\mathrm{X}_{2}\right)=$ 0,109. ini menunjukkan besarnya pengaruh variabel tersebut terhadap keputusan mengunjungi destinasi wisata syariah. Tanda positif menunjukkan koefisien arah hubungan yang positif. Dengan arti setiap ada kenaikan satu satuan variabel sosial, maka keputusan mengunjungi destinasi wisata syariah akan naik sebesar 0,109 kali dengan anggapan faktor yang lain konstan (ceteris paribus).

Koefisen regresi variabel individu $\left(\mathrm{X}_{3}\right)$ $=0,060$. ini menunjukkan besarnya pengaruh variabel tersebut terhadap keputusan mengunjungi destinasi wisata syariah. Tanda positif menunjukkan koefisien arah hubungan yang positif. Dengan arti setiap ada kenaikan satu satuan variabel individu, maka keputusan mengunjungi destinasi wisata 
syariah akan naik sebesar 0,060 kali dengan anggapan faktor yang lain konstan (ceteris paribus).

Koefisen regresi variabel psikologis $\left(\mathrm{X}_{4}\right)=0,380$. ini menunjukkan besarnya pengaruh variabel tersebut terhadap keputusan mengunjungi destinasi wisata syariah. Tanda positif menunjukkan koefisien arah hubungan yang positif. Dengan arti setiap ada kenaikan satu satuan variabel psikologis, maka keputusan mengunjungi destinasi wisata syariah akan naik sebesar 0,380 kali dengan anggapan faktor yang lain konstan (ceteris paribus).

Pembuktian hipotesis digunakan untuk melihat pengaruh variabel independen terhadap variabel terikatnya dalam hal ini adalah keputusan mengunjungi destinasi wisata syariah.

Untuk melihat pengaruh budaya terhadap keputusan mengunjungi destinasi wisata syariah digunakan uji statistik t. Uji statistik t bertujuan untuk menguji pengaruh secara parsial antar variabel independen terhadap variabel dependen yang membandingkan $t$ hitung dengan $t$ tabel serta melihat nilai signifikansinya.

Hasil pengujian hipotesis pertama pada penelitian ini dapat dilihat pada tabel berikut:

Tabel 5. Pembuktian Hipotesis Pertama

\begin{tabular}{|llccc|}
\hline $\begin{array}{c}\text { Variabel } \\
\text { Independen }\end{array}$ & $\begin{array}{c}\mathbf{t} \\
\text { hitung }\end{array}$ & $\begin{array}{c}\mathbf{t} \\
\text { tabel }\end{array}$ & Sig. & Keterangan \\
\hline Budaya $\left(\mathrm{X}_{1}\right)$ & 12,631 & 1,984 & 0,000 & 3erpengaruh \\
\hline
\end{tabular}

Sumber: Output SPSS (data diolah)

Berdasarkan uji regresi, menghasilkan nilai t hitung variabel budaya sebesar 12,631 dengan nilai siginifikansi sebesar 0,000 . Dengan demikian, $\mathrm{t}$ hitung 12,631 $>\mathrm{t}$ tabel 1,984 dengan signifikansi $0,000<0,05$. Hal ini menunjukkan bahwa budaya berpengaruh positif terhadap keputusan mengunjungi destinasi wisata syariah.

Untuk melihat pengaruh sosial terhadap keputusan mengunjungi destinasi wisata syariah digunakan uji statistik t. Uji statistik $\mathrm{t}$ bertujuan untuk menguji pengaruh secara parsial antar variabel independen terhadap variabel dependen yang membandingkan $t$ hitung dengan $t$ tabel serta melihat nilai signifikansinya.
Hasil pengujian hipotesis kedua pada penelitian ini dapat dilihat pada tabel 6 berikut:

Tabel 6. Pembuktian Hipotesis Kedua

\begin{tabular}{|ccccc|}
\hline $\begin{array}{c}\text { Variabel } \\
\text { Independen }\end{array}$ & $\begin{array}{c}\mathbf{t} \\
\text { hitung }\end{array}$ & $\begin{array}{c}\mathbf{t} \\
\text { tabel }\end{array}$ & Sig. & Keterangan \\
\hline Sosial $\left(\mathrm{X}_{2}\right)$ & 3,576 & 1,984 & 0,001 & Berpengaruh \\
\hline
\end{tabular}

Sumber: Output SPSS (data diolah)

Berdasarkan uji regresi, menghasilkan nilai t hitung variabel sosial sebesar 3,576 dengan nilai siginifikansi sebesar 0,001 . Dengan demikian, $\mathrm{t}$ hitung 3,576 $>\mathrm{t}$ tabel 1,984 dengan signifikansi $0,001<0,05$. Hal ini menunjukkan bahwa sosial berpengaruh positif terhadap keputusan mengunjungi destinasi wisata syariah. Untuk melihat pengaruh individu terhadap keputusan mengunjungi destinasi wisata syariah digunakan uji statistik t. Uji statistik $t$ bertujuan untuk menguji pengaruh secara parsial antar variabel independen terhadap variabel dependen yang membandingkan $t$ hitung dengan $t$ tabel serta melihat nilai signifikansinya.

Hasil pengujian hipotesis ketiga pada penelitian ini dapat dilihat pada tabel 7 berikut

Tabel 7. Pembuktian Hipotesis Ketiga

\begin{tabular}{|ccccc|}
\hline $\begin{array}{c}\text { Variabel } \\
\text { Independen }\end{array}$ & $\begin{array}{c}\mathbf{t} \\
\text { hitung }\end{array}$ & $\begin{array}{c}\text { t } \\
\text { tabel }\end{array}$ & Sig. & Keterangan \\
\hline Individu $\left(\mathrm{X}_{3}\right)$ & 2,375 & 1,984 & 0,020 & Berpengaruh \\
\hline
\end{tabular}

Sumber: Output SPSS (data diolah)

Berdasarkan uji regresi, menghasilkan nilai t hitung variabel individu sebesar 2,375 dengan nilai siginifikansi sebesar 0,020. Dengan demikian, $\mathrm{t}$ hitung 2,675 $>\mathrm{t}$ tabel 1,984 dengan signifikansi $0,020<0,05$. Hal ini menunjukkan bahwa individu berpengaruh positif terhadap keputusan mengunjungi destinasi wisata syariah.

Untuk melihat pengaruh psikologis terhadap keputusan mengunjungi destinasi wisata syariah digunakan uji statistik t. Uji statistik t bertujuan untuk menguji pengaruh secara parsial antar variabel independen terhadap variabel dependen yang membandingkan $t$ hitung dengan $t$ tabel serta melihat nilai signifikansinya. 
Hasbullah: Dimensi Mistik Dalam...

Hasil pengujian hipotesis keempat pada penelitian ini dapat dilihat pada tabel 8 berikut

Tabel 8. Pembuktian Hipotesis Keempat

\begin{tabular}{|ccccc|}
\hline $\begin{array}{c}\text { Variabel } \\
\text { Independen }\end{array}$ & $\begin{array}{c}\mathbf{t} \\
\text { hitung }\end{array}$ & $\begin{array}{c}\mathbf{t} \\
\text { tabel }\end{array}$ & Sig. & Keterangan \\
\hline $\begin{array}{c}\text { Psikologis } \\
\left(\mathrm{X}_{4}\right)\end{array}$ & 11,540 & 1,984 & 0,000 & Berpengaruh \\
\hline
\end{tabular}

Sumber : Output SPSS (data diolah)

Berdasarkan uji regresi, menghasilkan nilai $\mathrm{t}$ hitung variabel individu sebesar 11,540 dengan nilai siginifikansi sebesar 0,000 . Dengan demikian, $\mathrm{t}$ hitung $11,540>\mathrm{t}$ tabel 1,984 dengan signifikansi $0,000<0,05$. Hal ini menunjukkan bahwa psikologis berpengaruh positif terhadap keputusan mengunjungi destinasi wisata syariah.

Selanjutnya hipotesis di atas di uji dengan menggunakan uji-F yang diperoleh melalui tabel Analisis Varians (Anova) seperti yang dijelaskan pada tabel 9 berikut :

Tabel 9. Pengujian Koefisien Regresi secara Simultan (Uji F) ANOVA $^{\text {D }}$

\begin{tabular}{|l|r|r|r|r|r|}
\hline Model & $\begin{array}{r}\text { Sum of } \\
\text { Squares }\end{array}$ & df & $\begin{array}{c}\text { Mean } \\
\text { Square }\end{array}$ & F & Sig. \\
\hline 1 Regression & 43.313 & 4 & 10.828 & 186.109 & $.000^{\circ}$ \\
Residual & 5.527 & 95 & .058 & & \\
Total & 48.840 & 99 & & & \\
\hline
\end{tabular}

a. Predictors: (Constant), X4_Psikologis, X3_Individu, X1_Budaya, X2_Sosial

b. Dependent Variable: Y_Keputusan

Sumber: Data Olahan

Tabel 9 menunjukkan bahwa nilai Fhitung adalah 186,109 dengan signifikan 0,000. Sementara itu diperoleh nilai F-tabel untuk $\alpha=0,05$ sebesar 2,46.

Dengan demikian karena F-hitung $>$ Ftabel, hal ini berarti dapat disimpulkan bahwa variabel variabel budaya, sosial, individu dan psikologis secara bersama-sama berpengaruh terhadap keputusan mengunjungi destinasi wisata syariah di Sumatera Barat.

Sebelumnya telah dilakukan pembuktian terhadap hipotesis dengan menghimpun data yang diperoleh dari para responden dan diolah dengan bantuan komputer yaitu program SPSS sehingga dapat dijelaskan pengaruh faktor-faktor perilaku yang terdiri dari budaya, sosial, individu dan psikologis terhadap keputusan keputusan mengunjungi destinasi wisata syariah, berikut ini dilanjutkan dengan pembahasan hasil analisis.

Faktor budaya memberikan pengaruh paling luas dan dalam pada perilaku konsumen. Para pelaku usaha jasa pariwisata harus mengetahui peranan yang dimainkan oleh budaya, subbudaya dan kelas sosial masyarakat. Budaya adalah penyebab paling mendasar dari keinginan dan perilaku seseorang. Dimensi dari budaya yan mempengaruhi keputusan masyarakat mengunjungi destinasi wisata syariah meliputi pengetahuan masyarakat tentang wisata syariah, kebiasaan masyarakat mengunjungi tempat-tempat wisata, faktor lingkungan sekitar, tingkat penghasilan dan tingkat pendidikan masyarakat.

Hal ini juga konsisten dengan pendapat Mas Oetarjo (2015) yang menyatakan bahwa dimensi budaya dalam perilaku konsumen adalah pengetahuan, kebiasaan, lingkungan, penghasilan, pendidikan.

Selain faktor budaya, perilaku seorang konsumen atau masyarakat dipengaruhi oleh faktor-faktor sosial seperti kelompok acuan, keluarga serta status sosial. Adapun indikator variabel sosial dalam penelitian ini terdiri dari adanya pengaruh dari orang lain, kondisi atau kebiasaan yang dilakukan oleh keluarga, keinginan seseorang untuk mengunjungi destinasi wisata syariah.

Faktor pribadi atau individu yang memberikan kontribusi terhadap perilaku konsumen terdiri dari: usia dan tahap siklus hidup, pekerjaan dan lingkungan ekonomi, gaya hidup, kepribadian dan konsep diri. Adapun indikator dari variabel individu pada penelitian ini adalah usia responden dan gaya hidup.

Pilihan pembelian seseorang dipengaruhi oleh empat faktor psikologis utama yaitu motivasi, persepsi, pembelajaran, serta keyakinan dan pendirian. Adapun indikator dari variabel psikologis pada penelitian ini adalah meliputi kebutuhan mengunjungi destinasi wisata syariah serta persepsi masyarakat terhadap wisata syariah di Sumatera Barat. 


\section{PENUTUP}

\section{Simpulan}

Berdasarkan hasil analisis dan pembahasan, mnaka dapat dikemukakan beberapa kesimpulan sebagai berikut: (1) hasil pengujian hipotesis pertama menunjukkan bahwa budaya berpengaruh positif terhadap keputusan mengunjungi destinasi wisata syariah artinya hipotesis pertama diterima, (2) hasil pengujian hipotesis kedua menunjukkan bahwa sosial berpengaruh positif terhadap keputusan mengunjungi destinasi wisata syariah artinya hipotesis kedua diterima, (3) hasil pengujian hipotesis ketiga menunjukkan bahwa individu berpengaruh positif terhadap keputusan mengunjungi destinasi wisata syariah artinya hipotesis ketiga diterima, (4) hasil pengujian keempat menunjukkan bahwa psikologis berpengaruh positif terhadap keputusan mengunjungi destinasi wisata syariah artinya hipotesis keempat diterima.

\section{Saran}

Berdasarkan hasil penelitian, maka dapat dikemukan saran yaitu diharapkan kepada pemerintah untuk dapat melakukan sosialisasi mengenai konsep dan tujuan pengembangan wisata syariah kepada masyarakat dan pelaku industri pariwisata di Sumatera Barat.

\section{DAFTAR PUSTAKA}

Bungin, Burhan. 2004. Metodologi Penelitian Sosial, Surabaya: Airlangga University Press.

Hamzah, Maulana.Mdan Yudiana, Yudi. 2015. Analisis Komparatif Potensi Industri Halal dalam Wisata Syariah dengan Konvensional

Global Muslim Travel Index (GMTI). 2016.

Kempar. 2015. Jumlah Kunjungan Wisatawan Mancanegara Menurut Pintu Masuk dan Kebangsaan. Jakarta: Kementerian Pariwisata.

Kotler, Philip, dan Kevin L. Keller. 2009. Manajemen Pemasaran jilid1. Alih Bahasa: Benyamin Molan. Edisi Ketiga
Belas. Alih Bahasa : Bob Sabran. Jakarta: Erlangga.

Kotler, Philip, dan Kevin L. Keller. 2009. Manajemen Pemasaran jilid 2. Alih Bahasa: Benyamin Molan. Edisi Ketiga Belas. Alih Bahasa : Bob Sabran. Jakarta: Erlangga.

Kuncoro, Mudjarad. 2007, Metode Kuantitatif Teori dan Aplikasi untuk Bisnis dan Ekonomi. Yogjakarta : IPD STIM YKPN.

Moleong, Lexy.J. 2005, Metodologi Penelitian Kualitatif, Bandung : Remaja Rosdakarya.

Narbuko. Chalil, Abu Achmadi, 2004, Metodologi Penelitian, Jakarta : Penerbit Bumi Askara.

Sarwono. J. 2009. Statistik Itu Mudah. Yogyakarta: CV Andi Offset.

Setiadi. 2005. Perilaku Konsumen: Konsep dan Implikasi Untuk Strategi dan Penelitian Pemasaran.

Sofyan, Riyanto. 2012. Prospek Bisnis Pariwisata Syariah. Jakarta : Republika.

Sugiyono. 2005. Metode Penelitian Bisnis, Bandung: Alfabeta

Suharso, Puguh. 2010. Model Analisis Kuantitatif. Jakarta : Indeks.

Unggul Priyadi. 2016. Pariwisata Syariah, Prospek dan Pengembangan. Yogyakarta: Penerbit UPP STIM YKPN. 